\title{
PENGARUH TARAF KONSENTRASI ATONIK DAN LAMA PERENDAMAN TERHADAP PERTUNASAN RIMPANG JAHE GAJAH ( Zingiber officinale Rose.)
}

\author{
Josina I B Hutubessy *', Sukar dan Karyoto S.A ${ }^{2)}$ \\ 1) Jurusan Agroekoteknoligi Fakultas Pertanian Uniflor, 2) Jurusan Agronomi Fakultas Pertanian Negeri \\ Papua
}

\begin{abstract}
The EiTects of Atonic Concentration Level and Soak Duration on Budding Jahe Gajah Rhizome

This research intends to know the effect of atonic concentration level in soak of- growing budding jahe gajah rhizome. This research is experiment methods used block multiple random design and used atonic concentration $0,04 \%, 0,06 \%, 0,08 \%$ and soak duration 1 hours, 3 hours and 5 hours- The result of research indicated that $0,08 \%$ atonic concentration use and 3 hours soak duration caused time for budded more better. No real effects of Atonic concentration on amount of bud, height of bud, length and amount of root.
\end{abstract}

\section{Keyword: Atonic concentration, soak duration.}

\section{PENDAHULUAN}

Jahe (Zingiber officinale Ros.) merupakan tanaman temu-temuan yang mempunyai potensi cukup tinggi untuk dibudidayakan. Jahe dapat dibedakan jenisnya dari aroma, warna, bentuk dan besar. Dari berbagai hal tersebut maka dikenal tiga klon jahe yaitu : Jahe gajah (Jahe badak), Jahe kecil (Jahe emprit) dan Jahe merah (Jahe sunti). Jenis jahe gajah lebih banyak dibudidayakan di Indonesia karena mempunyai beberapa keuntungan antnra. lain; produksi/hektar lebih tinggi dibanding produksi jahe jenis lainnya, selain itu peluang pasar terbuka lebar baik didalam negeri maupun !uar negeri, resiko kegagalan dapat ditekan serendah mungkin karena klon ini lebih tahan terhadap hama penyakit dan harga per kilogram rimpang lebih mahal yang berdampak pada pendapatan yang diterima petani jahe lebih tinggi (Santoso, 1989

Jahe termasuk tanaman banyak guna terutama rimpangnya dapat digunakan sebagai penyedap masakan seperti bumbu dapur, bahan industri minuman dan parfum, makanan keci!, juga dapat digunakan sebagai obat-obatan tradisional $\mathrm{y}^{\wedge} \mathrm{ng}$ digunakan untuk menyembuhkan beberapa penyakit seperti; kepala pusing encok, dan gatal-gatal, meningkatkan nafsu makan.

Menurut Santoso (1994) rimpang jahe mengandung $0,8-33 \%$ minyak atsiri dan \pm 3 $\%$. oleoresin, tergantung kepada klon jahe yang bersangkutan. Zat - zat yang terkandung dalam rimpang antara Iain; Vitamin A, Vitamin B dan Vitamin C, Lemak, Protein, Pati, Damar, asam organic, oleoresin (gingerin) dan minyak terbang (Zineron, Zingero!, Zingeberol, Zingeberin, Berneol, Sineol dan Faladren)
Menghadapi peluang besar jahe yang makin baik dan meluas maka pengembangan budidaya tanaman ini mempunyai potensi yang cukup besar untuk dikelola secara intensif.

Klon jahe akhir-akhir ini banyak diburu oleh para importer / eksportir. Bahkan para importer / eksportir sering mengeluh dan kecewa karena betapa sulitnya mendapatkan komoditas jahe gajah di lapangan, kalaupun ada jumlahnya sangat terbatas. Disamping itu juga masalah yang dihadapi pada umumnya masih bersifat sambilan.

Kurangnya minat petani untuk membudidayakan tanaman ini diduga dikarenakan oleh masa dormansinya yang panjang. Hal ini senada dengan pendapat Sudiarto, dkk (1989) mengungkapkan bahwa salah satu masalah dalam teknik budidaya tanaman temu-temuan adanya dormansi selama 2 - 3 bulan pada rimpang. Untuk itu perlu ada upaya yang dapat memperpendek masa dormansinya. Upaya ini dapat dilakukan antara lain dengan pemberian zat pengatur tumbuh yang dapat merangsang pertumbuhannya.

Salah satu upaya untuk menyeragamkan perkecambahan dan pertumbuhan tunas dari rimpang yaitu dengan menggunakan zat pengatur tumbuh (ZPT) atau hormone. Santoso (1994) menuliskan bahwa masa dormansi jahe gajah 2,5 bulan. Menurut Lingga (1994) zat pengatur tumbuh auksin akan berperan untuk merangsang perakaran, stek/tunas. Salah satu zat pengatur tumbuh dari kelompok auksin adalah atonik dalam bentuk cairan yang fungsi utamanya meningkatkan keluarnya kuncup, meransang pertumbuhan akar, mengaktifkan penyerapan unsure hara dan memperbaiki kwalitas hasil.

Penggunaan atonik pada berbagai tanaman sudah banyak dilakukan seperti pada tanaman kunyit dengan kosentrasi 0,06 \% selama lama perendaman 3 jam lebih efektif dan dapat memacu 
pertumbuhan pada umur 35 hari (Sumanto dalain Rukmana,1995).

Berdasarkan uraian diatas maka periu diadakan penelitian untuk mempercepat waktu tumbuh tunas tanaman jahe gajah dengan mempergunakan zat pengatur tumbuh.

\section{BAHAN DAN METODE}

Penelitian ini dilaksanakan di Manokwari sejak bulan November 2001 - Februari 2002. Pengenceran atonik dan perendaman dilakukan di Lab FP Papua, percobaan lapangan dilaksanakan di rumah plastic yang terletak pada ketinggian 0-6 meter dari permukaan laut. Bahan - bahan yang digunakan adalah nmpang jahe gajah, atonik, dithen M-45, tanah, kotoran ayam sebagai pupuk dan aqua sedangkan akit yang digunakan timbangan, gelas ukur, pengaduk, pengayak, ember, pisau, sekop, polibag, thermometer, dan alat tulis menulis.

Metode penelitian yang digunakan adalah metode eksperimen. Penelitian ini menggunakan Rancangan Acak Kelompok \{ RAK ). Faktor A Kosentrasi larutan atonik terdiri dari: A0 (Kontrol), Al (0,04\%), A2 (0,06\%), A3 $(0,08 \%)$. Faktor B lama perendaman terdiri dari Bl (1 jam), B2 (3 jam), B3 (5 jam). Dengan demikian kombinasi perlakuan 10 perlakuan yaitu A0B0, A1B1, A1B2, A1B3, A2B1, A2B2, A2B3, A3B1, A3B2, A3B3. Setiap perlakuan diulang sebanyak 3 kali sehingga diperoleh 30 satuan percobaan.

Model Matematika Rancangan yang digunakan adalah :

Dimana:

$$
Y i j=j i+T i+B j+L i j
$$

$$
\begin{aligned}
\text { Yij } & =\text { Nilai pengamatan perlakuan ke-i pada kelompok ke } \mathrm{j} \\
\mathrm{l} & =\text { Nilai tengah pengamatan } \\
\mathrm{Ti} & =\text { Pengaruh perlakuan ke }-\mathrm{i} \\
\mathrm{Bj} & =\text { Pengaruh kelompok ke }-\mathrm{j} \\
\mathrm{Zij} & =\text { Galat percobaan pada perlakuan ke I, kelompok ke } \mathrm{j}
\end{aligned}
$$

Media yang digunakan adalah campuran tanah dan kotoran aym dengan perbandingan 2:1 (untuk tanah 1350 gram dan kotoran ayam 675 gram) bobo media/poly bag $2 \mathrm{~kg}$. Terlebih dahulu tanah diayak dengan ayakan 5 mm,kemudian dibiarkan kering udara. Selanjutnya diadakan pengisian tanah ke daiam polybag dengan ukuran 20x30.Polybag yang telah berisi tanah diatur menurut blok dan lajur dengan jumlah seluiuhnya 90 polybag.

Rimpang dipilih yang sehat dan tidak cacat/tidak rusak.Rimpang ini ditimbang dengan berat untuk kelompok I 40-46 gram,Kelompok II 47-53 gram,dan kelompok III 54-60 gram.Setiap kelompok memiliki 3-5 tunas kemudian dicuci dan dikeringkan.

Metode yang dilakukan dalam pemberian atonik adalah metode perendaman,dimana larutan atonik diambil $0,8 \mathrm{ml}, 1,2 \mathrm{ml}$ dan $1,6 \mathrm{ml}$ kemudian dimasukan kedalam wadah/ember yang sudah diisi 21 iter aqua untuk kosentrasi $0,04 \%, 0,05 \%$ dan $0,08 \%$.

Rimpang yang telah disiapkan kedalam wadah yang telah berisi larutan atonik.Caranya:ember yang pertama yang telah berisi larutan dengan kosentarasi 0,04\% dimasukan 9 rimpang yang akan direndam selama 5 jam,selang waktu2 jam masukan kembaii 9 rimpang yang akan direndam selama 3 jam,selang waktu 2 jam masukan kembaii 9 rimpang yang akan direndam selama 1 jam, dengan maksud bahwa saat diambil untuk tanam dapat secara serempak (untuk membedakan rimpang akan diberi tanda dengan menggunakan tali raffia).Untuk ember kedua dan ketiga cara melakukannya sama dengan ember pertama.Dengan demikian setiap ember terdapat 27 rimpang.

Rimpang yang teiah diberi perlakuan selanjutnya ditanam pada media yang disiapkan. Agar rimpang tidak rusak, terlebih dahulu media diberi lubang yang agak besar dari diameter rimpang,kemudian rimpang ditanam dan sekitar media dipadatkanjahe ditanam dengan cara ditidurkan.

Penyiraman disesuaikan dengan kondisi tanah agar air selalu berda pada kapasitas lapang. Untuk menghindari kebusukan akar,maka digunakan Dithane M-45 dengan cara sebelum rimpang direndam dilarutan atonik,terlebih dahulu rimpang tersebut di rendam dilarutan Atonik, terlebih dahulu rimpang'tersebut direndam dalam Dithane M-45 selama 30 menit.

Pengamatan yang diiakukan adalah sebagai berikut:

1. Waktu mulai bertunas (hari) sampai tunas tumbuh pertama kali pada semua tanaman dalam setiap percobaan.

2. Jumlah tunas yang tumbuh dihitung dari setiap rimpang.

3. Tinggi tunas $(\mathrm{cm})$ 
Tinggi tunas adaiah : Diukur pada tunas berumur satu minggu

4. Panjang akar $(\mathrm{cm})$

Panjang akar diukur pada saat tunas berumur 6 minggu

5. Jumlah akar

Jumlah akar di hitung selama tunas berumur 6 minggu.

Variabel penunjang adaiah:

1. $\operatorname{Suhu}\left({ }^{\circ} \mathrm{C}\right)$

2. Kelembaban $(\%)$

\section{Analisa Data}

Analisa data dilakukan dengan menggunakan analisa ragam dan bila perlakuan memberikan pengaruh yang bermakna.maka akan dilanjutkan dengan Uji Beda Nyata Jujur (BNJ).

\section{HASIL PEMBAHASAN}

\section{Pertumbuhan Tunas}

Perlakuan atonik dengan berbagai tingkat kosentarasi dan lama perendaman perpengaruh nyata terhadap hari muncul' tunas,sedangkan jumlah tunas dan tinggi tunas menunjukan bahwa kosentrasi dan perlakuan perendaman tidak berpengaruh. Rataan dari perlakuan kosentrasi atonik dari hasil uji BNJ disajikan pada Tabel 1 .

Tabel 1. Hari Muncul Tunas, Jumlah Tunas, Tinggi Tunas (cm).

\begin{tabular}{clcc}
\hline Perlakuan & H.M.T & Jumlah Tunas & Tinggi Tunas (cm) \\
\hline Kontrol & $46,66 \mathrm{c}$ & 1,00 & 1,89 \\
A1B1 & $31,16 \mathrm{ab}$ & $1, \mathrm{U}$ & 1,88 \\
A1B2 & $33,13 \mathrm{ab}$ & 1,33 & 1,76 \\
A1B3 & $37,16 \mathrm{~b}$ & 1,33 & 1,85 \\
A2B1 & $36,38 \mathrm{~b}$ & 141 & 1,95 \\
A2B2 & $33,55 \mathrm{ab}$ & 1,00 & 1,89 \\
A2B3 & $35,4 \mathrm{ab}$ & 1,22 & 2,00 \\
A3B1 & $33,88 \mathrm{ab}$ & 1,22 & 1,83 \\
A3B2 & $28,44 \mathrm{a}$ & 1,22 & 2,40 \\
A3B3 & $34 \mathrm{ab}$ & 1,22 & 2,30 \\
\hline
\end{tabular}

Keterangan : Angka-angka yang selajur diikuti huruf yang sama tidak berbeda nyata pada uji BNJ.(0,05)

Berdasarkan uji lanjutan kita lihat bahwa hari munculnya tunas perlakuan A3B3 berbeda nyata dengan perlakuan lainnya.Sehingga A1B1 mempunyai pengaruh yang sama dengan perlakuan A1B2, A1B3 danA2BI. Perlakuan A2B2 memberikan pengaruh yang sama dengan A2B3, A3B1 dan A3B3. Dari semua perlakuan berbeda nyata dengan control.

Hasil penelilian menunjukkan bahwa dalam kosentrasi Atonik 0,08 \% setama perendaman 3 jam telah dicapai kosentrasi yang dapat merangsang pertunasan lebih cepat. Hal ini sesuai dengan pendapat Manurung (1983) dalam Setiawan (1986) yang mengatakan bahwa larutan atonik sebagai zat pengatur tumbuh menstimulir proses metabolisme tanaman,sehingga mendorong pertumbuhan vegetatif

Menurut Wattimena (1990) dalam Amisnaipa (1992) hal yang harus diperhatikan dalam pemberian zat pengatur tumbuh adaiah zat tumbuh tersebut harus sampai pada jaringan target. Perendaman rimpang dalam larutan zat pengatur tumbuh merupakan sa!ah satu cara agar zat yang diberikan dapat diabsorsi dan ditraslokasi kedalam jaringan rimpang dimana dapat tumbuhnya akar dan tunas an.

Atonik yang direndam selama 3 jam ke dalam jaringan rimpang mampu meningkatkan kosentrasi auksin yang sesuai bagi pertumbuhan tunas. Pada dasarnya waktu perendaman rimpang yang singkat belum nampak karena auksin yang diserap masih kurang, sedangkan perendaman terlalu lama akan menyebabkan kosentrasi auksin dalam jaringan rimpang relative tinggi sehingga

s, terjadi penurunan bahkan menghambat pertumbuhan rimpang.

Pada tabel 1 terlihat bahwa perlakuan atonik pada berbagai kosentrasi tidak memberikan pengaruh yang nyata terhadap jumlah tunas. Namum demikian rimpang yang direndam dalam atonik kosentrasi 0,04\% cenderung lebih banyak tunasnya dibandingkan dengan lainnya. Demikian juga dengan tinggi tunas,rimpang yang direndam dalam larutan atonik dengan kosentrasi 0,08\% lebih tinggi dari lainnya. Kenyataan ini menunjukan bahwa pemberian atonik dapat meningkat jumlah tunas dan tinggi tunas walaup.um tidak nyata. Hal ini diduga karena adanya factor yang mendukung hidupnya stek seperti kandungan dalan makanan (karbohidrat). Kandungan pati dari rimpang jahe tua mencapai 
lebih kurang $50 \%$ di bandingkan dengan rimpang muda (Pur seglove et a!., 1981 dalam Karsina, 1983 yang dikutip oleh Santi Utami, 1995). Karbohidrat diperlukan sebagai sumber pertunasan sampai terbentuknya akar.

Hasil pengukuran suhu udara dan kelembaban rata-rata adalah $26,47^{\circ} \mathrm{C}$ dan $89,89 \%$. Keadaan ini sesuai untuk pertumbuhan tanaman jahe yang membutuhkan suhu udara antara $25-30^{\circ} \mathrm{C}$ (Santoso,1994)

\section{Pertumbuhan Akar}

Panjang akar dan jumlah akar berdasarkan tabel 2 terlihat bahwa perlakuaan kosentrasi atonik dan lama perendaman tidak berpengaruh nyata.

Tabel 2. Rataan Panjang Akar (cm) dan jumlah akar

\begin{tabular}{ccc}
\hline Perlakuan & Panjang akar $(\mathrm{cm})$ & Jumlah akar \\
\hline Kontrol & 19,93 & 8,88 \\
A1B1 & 18,09 & 9,66 \\
A1B2 & 18,95 & 9,24 \\
A1B3 & 18,36 & 9,16 \\
A2B1 & 17,73 & 9,05 \\
A2B2 & 16,65 & 9,66 \\
A2B3 & 19,55 & 9,20 \\
A3B1 & 17,67 & 9,25 \\
A3B2 & 21,19 & 11,16 \\
A3B3 & 18,76 & 9,01 \\
\hline
\end{tabular}

\begin{abstract}
Perlakuan atonik pada berbagai kosentrasi tidak memberikan perbedaan terhadap panjang akar dan jumlah akar. Namum demikian rimpang yang direndam dalam kosentrasi Atonik 0,08\% selama perendaman 3 jam cenderung memiliki panjang akar dan jumlah akar lebih panjang dan banyak,sedangkan pada perlakuan lainnya Dengan demikian pemberian Auksin tambahan atas mempercepat pembentukan jaringan bam (Kallus),sehingga imisiasi pembentukan akar akan lebih dipercepat.Sintesis Auksin akan terjadi dengan sendirinya pada jaringan yang akan tumbuh.
\end{abstract}

Hal ini telah di buktikan Heddy (1986) dalam Amisnaipa (1992) bahwa kosentrasi auksinpada jaringan maristem (pucuk,batang dan daun muda) relative lebih tinggi dibandingkan pada daun,batang dan akar sudah dewasa.

Perendaman rimpang ke dalam larutan atonik dapat meningkatkan proses metabolisme dan perombakan kabohidrat sebagai bahan makanan daiam rimpang. Sehingga auksin alami yang berada pada rimpang akan meningkatkan aktifitasnya. Dengan demikian maka proses pembentukan dan pertumbuhan akar juga akan meningkatkan.

Menurut Sumarny (1983) dan Pandang (1983) daiam Setiawan (1986) pemberian atonik pada dosis yang tepat akan merangsang pertumbuhan akar dan cepat berkembang. Sandra atas segala dorongan serta semua hal yang menyenangkan pendek dan sedi kit.Pada konsentrasi Atonik yang tinggi dan perendaman yang lama akan menghambat pertumbuhan.

Kenyataan ini menunjukkan bahwa pemberian auksin buatan (larutan atonik) nampak lebih berperan dalam meningkatkan proses pembelahan,pernanjangan sel dan meningkatkan proses metabolisme tanaman.

Dengan adanya perakaran yang panjang dan luas maka tanaman yang lebih banyak mengambil unsur hara dari dalam tanah. Sejalan dengan itu tbtosintesis juga akan lebih aktif.

\section{SIMPULAN}

Perlakuan kosentrasi atonik pada 0,08 \% dan lama perendaman 3 jam memberikan pengaruh yang lebih baik untuk waktu bertunas. Sementara itu perlakuan atonik berpengaruh pada had muncul tunas tetapi tidak berpengaruh pada jumlah tunas,tinggi tunas dan panjang akar.

\section{UCAPAN TERIMA KASIH}

Bapak Rektor Universitas Negeri Papua, Dekan Fakultas Pertanian, Ketua Jurusan dan Ketua Program Study Universitas Negeri Papua, Rekan-rekan GMKI EXACTA 1, ASTRI dan VILANOVA. Orang Tua, Kakak, Adik, Rudy dan 


\section{DAFTAR PUSTAKA}

Amisnaipa, 1992 Pengaruh berbagai macam bahan stek dan lama perendamannya dalam lama perendamannya dalam larutan

Anonim. Dosis Atonik Terhadap pertumbuhan dan Produksi tanaman Kedelai (Glicyne max.L.Mari).Faperta Uncen Manokwari

Rukmana,R.1995. Kunyit. Penerbit Kanisius Jakarta

Sahilatua,DJ.1984. Atonik dan tanggapannya terhadap semai Advokat.Departemen Pertanian/Kehutanan.Universitas Pattimura ambon.

Santoso,H.B.1989Jahe.Penerbit Kanisius.Jakarta

Santoso,H.B. 1994. Jahe Gajah.Penerbit Kanisius Jakarta

Wahyuni,S.U.1995. Pengaruh Kosentrasi Zat Pengatur Tumbuh IB A Terhadap Pertumbuhan dan Perkembangan
Jahe.Faperta Uncen Manokwari (Tidak diterbitkan). 